Amasya İlahiyat Dergisi - Amasya Theology Journal

ISSN 2667-7326 | e-ISSN 2667-6710

Aralık / December 2020, 15: 395-419

\title{
“Lehve'1-Hadis"in Müziğe Tahsisinin Tefsir Açısından Değerlendirilmesi
}

\section{Faysal ARPAGUȘ}

Dr. Öğr. Üyesi, Tokat Gaziosmanpaşa Üniversitesi, İslami İlimler Fakültesi, Kıraat Anabilim Dalı

Assistant Professor, Tokat Gaziosmanpaşa University, Faculty of Islamic Sciences, Department of Qirāah

Tokat, Turkey faysal.arpagus@gop.edu.tr orcid.org/0000-0001-9607-0078

\section{Makale Bilgisi / Article Information}

Makale Türü / Article Types: Araştırma Makalesi / Research Article

Geliş Tarihi / Received: 10 Ağustos / August 2020

Kabul Tarihi / Accepted: 22 Eylül / September 2020

Yayın Tarihi / Published: 30 Aralık / December 2020

Yayin Sezonu / Pub. Date Season: Aralık / December

Sayı / Issue: 15 Sayfa / Pages: 395-419

Atıf / Cite as: Arpaguş, Faysal. "'Lehve'l-Hadis'in Müziğe Tahsisinin Tefsir Açısından Değerlendirilmesi [Evaluation of the Allocation of "Lahw al-ḥadith" to Music in Terms of Tafsir]". Amasya Illahiyat Dergisi-Amasya Theology Journal 15 (December 2020): 395-419. https://doi.org/10.18498/amailad.778622.

İntihal / Plagiarism: Bu makale, en az iki hakem tarafından incelendi ve intihal içermediği teyit edildi. / This article has been reviewed by at least two referees and scanned via a plagiarism software.

Copyright ( Published by Amasya Üniversitesi, İlahiyat Fakültesi / Amasya University, Faculty of Theology, Amasya, 05100 Turkey. All rights reserved. https://dergipark.org.tr/amailad. 
396 | F. ARPAGUŞ / 'Lehve'1-Hadis'in Müziğe Tahsisinin Tefsir Açısından Değerlendirilmesi

\section{Evaluation of the Allocation of "Lahw al-hadith" to Music in Terms of Tafsir} Abstract

The Prophet Mohammed stated in a hadith that it is not lawful for training to sing, buying, and gaining fee of selling the female singers. A relationship was established between the hadith and verse "But there are, among men, those who purchase idle tales, without knowledge, to mislead from the Path of Allah and throw ridicule (on the Path): for such there will be a Humiliating Penalty." (Loqmān 31/6) and in addition to people such as Mojāhid, Sofyān al-Thawrī, and Ibn Wahb, many later commentators interpreted the lahw al-hadith in the verse as music. Based on the explanation of lahw al-hadith as music in many fiqh books, this verse is considered as evidence that music is prohibited in Islam. In our opinion, the problem originates from the allocation of the term lahw al-hadith to music. In this framework, the concepts determined for research consists of allocation, interpretation, lahw al-hadith and music.

Allocation is the opposite of generalization, which means keeping one thing separate from the whole so that others do not participate in it by rule. This occurs as a result of an interpretation. The determination of the meaning to be given to the law text is called interpretation, as well as the science that mentions the state of utterance of the words of the Qur'ān, the meanings attributed to them, and the elements that complement them. At this point, ijtihād is an activity of interpretation, in other words, is a commentary. The comment may be accurate as well as inaccurate; because the interpretation of lahw al-hadith as music is not a definite interpretation. When the allocation of something is legally ordered that is freedom and prohibition or whatever is ruled between the two; it means that this provision is reserved only for it. In this case, those who are excluded from allocation are considered separately from the provision in question.

The article primarily sought to determine whether lahw al-hadith, which is obscure and general was allocated by some commentators. For this purpose, starting from the classical age of Islam the views of some commentators was consulted. It is really thought to claim that what is meant by lahw al-hadith is music by referring to a hadith that is described as "weak" and "garīb" in terms of deed and text as if its signification is definite.

In the Qur'ān, there is no verse stating that music is forbidden such as alcohol, interest and other forbidden things, and there is also no verse indicating this in the context of the interpretation of the Qu'rān with the Qu'rān. However, it cannot be said that there is no evidence for music in the form of obscenity and unlawful. In this case, the way in which The Prophet includes music in his life 
in the context of the interpretation of the Qu'rān with sunnah will reveal as a measure for Muslims. It is known that He allows the use of music in weddings, festivals and entertainments within legitimate boundaries, and sometimes even encourages them; but it is also the case that he has a harsh attitude towards those who entertain themselves and neglect their religious duties and responsibilities. But based on this, to claim that music is completely forbidden, it contains all the branches of the known art performed by sound and instrument as mentioned in the description of music leading to salah, adhan and reading the beautiful Qu'rān is also forbidden. So there is a limit and a measure set by religion for legitimate music. However, the phrase lahw alhadith, which is mentioned in the verse, is different from all these expressions.

In the article, the data in some classical tafsir and fiqh sources were collected, and the discussions of today's theology researchers on the subject were included. By making an evaluation in the light of the data, it has been tried to clarify whether it is possible or not to allocate lahw al-hadith to music and if possible, to what extent it is possible According to this, considering the context and other methods of interpretation, it has been concluded that it would be more appropriate to explain the lahw al-hadith not only as music, but as all kinds of words that prevent from the path of Allah and His Messenger in general. As a result of such an approach, it was emphasized that Muslims would be in agreement within the framework of legitimate limits with music, which is the concrete manifestation of feelings that Allah has places on human nature.

Keywords: Tafsir, Lahw al-hadith, Music, Discussion of Allocation-and Generalization (tahsīs-ta'mīm), Effect of Narration.

\section{“Lehve'l-Hadis”in Müziğe Tahsisinin Tefsir Açısından Değerlendirilmesi Öz}

Hz. Peygamber (a.s.) bir hadiste, şarkı söylemesi için muğanniyelerin yani şarkıcı kadınların eğitilmelerinin, alınıp satılmalarının helal olmadığını ve buradan elde edilen ücretin haram kılındığını belirtmiştir. Bu hadisle, "İnsanlardan öyleleri de vardır ki Allah'ın yolundan alıkoymak için lehve'lhadisi satın alır." (Lokmân 31/6) âyeti arasında münasebet kurulmuş; Mücâhid, Süfyân es-Sevrî, İbn Vehb gibi kimselere ilaveten sonraki pek çok müfessir, âyetteki "lehve'l-hadis"i ğinâ/müzik olarak tefsir etmiştir. Çoğu fikıh kitabında da "lehve'l-hadis"in müzik olarak izah edilmesinden hareketle, bahsi geçen âyet, İslâm'da müziğin yasaklandığına delil sayılmıştır. Kanaatimizce problem, lehve'l-hadis tabirinin müziğe tahsisinden kaynaklanmaktadır. Bu çerçevede 
398 | F. ARPAGUŞ / 'Lehve'1-Hadis'in Müziğe Tahsisinin Tefsir Açısından Değerlendirilmesi

araştırma için belirlenen kavramlar; tahsis, tefsir, lehve'l-hadis ve müzikten ibarettir.

Tahsis; bir şeyi hükümce, diğerleri ona iştirak etmeyecek şekilde bütünden ayrı tutmak demek olup genelleştirmenin zıddıdır. Bu ise bir yorum (tefsir) neticesinde ortaya çıkar. Kanun metnine verilecek mananın tespitine yorum dendiği gibi Kur'ân lafızlarının söyleniş keyfiyetinden, medlûllerinden hareketle onlara yüklenen anlamlarla birlikte, bunları tamamlayan unsurlardan bahseden ilme de tefsir denmiştir. Bu noktada içtihat, bir yorumlama faaliyeti, diğer bir deyişle, tefsir olmaktadır. Yorum, isabetli olabileceği gibi hatalı da olabilir. Çünkü lehve'l-hadisin müzik olarak tefsir edilmesi, delaleti kat'î bir yorum değildir. Hukuken veya fıkhen, bir şeyin tahsisine hükmedildiğinde serbestlik ve yasaklık (helallik ve haramlık) veya bu ikisi arasında her neye hükmedilirse, bu hükmün sadece ona has kılındığı anlamına gelir. Bu durumda, tahsis dışında kalan fertler, söz konusu hükümden ayrı mütalaa edilir.

Makalede öncelikli olarak, mücmel birakılan lehve'l-hadisin, kimi yorumcular tarafından tahsis edilip edilmediği belirlenmeye çalışılmıştır. Bunun için İslam'ın klasik çağından başlanarak müfessir, muhaddis ve fakih, bazı yorumcuların görüşlerine müracaat edilmiştir. Senet ve metin açısından "zayıf" ve "garib" olarak nitelendirilen bir hadisi referans alarak delaleti kat'îymiş gibi, lehve'l-hadisle kastedilenin müzik olduğunu iddia etmek, gerçekten düşündürücüdür.

Kur'ân'da içki, faiz ve diğer haramlar gibi müziğin yasaklandığını belirten bir âyet olmadığı gibi Kur'ân'ın Kur'ân'la tefsiri bağlamında da buna delalet eden bir ayet bulunmamaktadır. Ancak fuhşiyât ve münkerât kabilinden olan müzik için de delil yoktur denemez. Bu durumda Kur'ân'ın sünnetle tefsiri bağlamında Hz. Peygamber'in (a.s.) hali hayatında müziğe ne şekilde yer verdiği, biz Müslümanlar için bir ölçü ortaya koyacaktır. Onun (a.s.) düğünlerde, bayramlarda ve meşru sınırlar içerisinde yapılan eğlencelerde müziğin kullanılmasına izin verdiği hatta zaman zaman teşvik ettiği; fakat eğlenceye dalıp dinî vazife ve sorumluluklarını ihmal edenlere karşı da sert bir tutum sergilediği vakidir. Ama buradan hareketle müziğin bütünüyle haram olduğunu iddia etmek, müziğin tarifinde de geçtiği üzere, ses ve âlet (çalgı) ile icrâ edilen malûm san'atın bütün şubelerini ihtiva etmesi bakımından, salâda, ezanda ve güzel Kur'ân okumada ortaya çıkan müziğin de haram olduğunu iddia etmektir. O halde dinin meşru müzik için koyduğu bir sınır ve ölçü vardır. Ancak tüm bunlarla ayette geçen lehve'l-hadis ifadesi, birbirinden farklı şeylerdir. 
Makalede bazı klasik tefsir ve fıkıh kaynaklarındaki veriler toplanmış, günümüz ilahiyat araştırmacılarının konuya dair tartışmalarına yer verilmiştir. Veriler ışı̆̆ında bir değerlendirme yapılarak lehve'l-hadisin müziğe tahsisinin mümkün olup olmadığı, mümkünse hangi ölçüde mümkün olduğu açıklığa kavuşturulmaya çalışılmıştır. Buna göre bağlam ve sair tefsir etme yöntemleri göz önüne alınarak lehve'l-hadisin sadece müzik olarak değil, genel manada, Allah ve Rasûlünün yolundan alıkoyan her türlü söz olarak tevil edilmesinin daha isabetli olacağı kanaatine varılmıştır. Böyle bir yaklaşım sonucunda ise Müslümanların, Allah'ın insan fıtratına yerleştirdiği, duyguların somut tezahürü olan müzikle, meşru sınırlar çerçevesinde uzlaşı içerisinde olacağ vurgulanmıştır.

Anahtar Kelimeler: Tefsir, Lehve'l-hadis, Müzik, Tahsis-ta'mîm Tartışması, Rivâyetin Etkisi.

\section{Giriş}

Müslümanlar, öteden beri, herhangi bir meselenin hükmü konusunda önce Kur'ân'a, sonra da sünnete müracaat etmişlerdir. Bu, tabiî bir durumdur. Kur'ân'ın, bir bakışta ne demek istendiğini ortaya koyan sarih ifadeleri olduğu gibi manasının ancak bir karine veya başka bir delille tespit edilebileceği kapalı ifadeleri vardır. Lafzın neye delalet ettiği açı olan yerde anlam bellidir; ancak kapalı olduğu ve tam olarak neye delalet ettiği belli olmayan yerlerde bir hükme varılırken kapsam bazen genişletilmekte, bazen daraltılmakta, bazen de bağlam ve sair durumlar göz ardı edilerek parçacı yaklaşım sergilenebilmektedir. Yorum faaliyetiyle açık olan mananın bazen muğlaklaştırıldığı da söz konusu olmaktadır. İnsan faktörü göz önüne alındığında verilen hükümler içerisinde doğru ve geçerli, yanlış ve geçersiz ya da kısmen geçerli olanlar olacaktır. Nitekim: "İnsanlardan öyleleri de vardır ki Allah'ın yolundan alıkoymak için laf eğlencesi satın alır. "1 meâlindeki âyette geçen "lehve'l-hadis" tabiri için de böyle bir durum söz konusudur. Çünkü "laf eğlencesi" şeklinde aktarılan "lehve'l-hadis", rivâyete dayalı tefsirlerin çoğunda "ğinâ/müzik" olarak tefsir edilmiştir. ${ }^{2}$

1 Kur'ân-ı Kerîm ve İzahlı Meâli (Türkçe Anlamı), çev. Muhammed Hamdi Yazır, haz. Dücane Cündioğlu (İstanbul: Nizam Yayınları, 1998), Lokmân 31/6.

2 İlgili kaynaklar, hicrî 1. asırdan 4. asra kadar kronolojik sıra ile çalışmanın "Klasik tefsir kaynaklarında lehve'l-hadîs" bölümünde ayrıntılı olarak zikredilmiştir. 
400 | F. ARPAGUŞ / 'Lehve'1-Hadis'in Müziğe Tahsisinin Tefsir Açısından Değerlendirilmesi

Makale, İslam dininde müziğin helalliği veya haramlığ konusunda olmayıp Lokmân sûresi 6. âyette yer alan "lehve'l-hadis" tabirini, daraltıcı yaklaşımla ğinâ/müzik olarak tefsir edenlerin yaptıkları bu tahsiste ne kadar isabetli olduğuyla alakalıdır. Ancak makale içerisinde birbiriyle sıkı irtibat olması sebebiyle yine de müziğin hükmü konusundaki görüşlere ihtiyaç ölçüsünde yer verilecektir. Bunun için önce araştırmanın temel kavramları belirlenip açıklanacak, sonra da söz konusu hadisin, âyetle birlikte hadis kitaplarında ne şekilde geçtiğine yer verilecektir. Ardından belli başlı bazı klasik tefsir ve fikıh kitaplarında bu lafzın ne şekilde anlaşıldığı, iddia edildiği gibi daraltıcı yorum benimsenerek tahsis yapılıp yapılmadığı belirlenmeye çalışılacaktır.

Müziğin helalliği ve haramlığı konusunda, Hz. Peygamber'in (a.s.) hali hayatındaki fiili durumun ne şekilde tezahür ettiği de önemlidir. Bu fiili durumdan hareketle, "Acaba söz konusu âyet için tahsise giden bir yol var mı?" sorusu cevap beklemektedir. Yine tartışmaların güncelliğini koruması sebebiyle günümüz ilahiyat araştırmalarında "lehve'l-hadis" in nasıl anlaşıldığ 1 da bize bir perspektif sunacaktır. Bu sebeple konu ile ilgili araştırmalar gözden geçirilerek elde edilen veriler, tefsir usûlü açısından değerlendirilerek alana katkı sağlanması hedeflenmiştir.

\section{Kavramsal analizler ve tanımlar}

Makale için söz konusu kavramlar; tefsir, lehve'l-hadis, müzik ya da mûsikî ve tahsis ve ta'mîm kavramlarıdır.

\subsection{Tefsir}

Kelime olarak tefsir; açıklamak, ${ }^{3}$ gizli manayı keşfetmek ve makul manayı ortaya çıkarmak ${ }^{4}$ anlamındadır. Istılahî anlamda ise 'Kur'ân lafızlarının söyleniş keyfiyetinden, lafızların medlûllerinden, gerek münferit gerekse terkip halinde hükümler ve terkiplere yüklenen anlamlarla birlikte bunları tamamlayan unsurlardan bahseden ilim's diye tarif edilmiştir. Teşrîi, kazaî, ilmî, gâî, lafzî ve hukukî olmak üzere

3 Zeynüddîn Ebû Abdullah Muhammed b. Ebîbekr b. Abdilkâdir er-Râzî, Muhtâru'ssihâh, thk. Yusuf eş-Şeyh Muhammed (Beyrut: el-Mektebetü'l-'Asriyye, 1420/1999), "fesr", 239.

4 Muhammed b. Mükerrem İbn Manzûr, Lisânü'l-'Arab (Beyrut: Dâr-u Sâdır, 1414), "fesr", 5/55.

5 Mennân b. Halîl el-Kattân, Mebâhis fì 'ulûmi'l-Kur'ân (b.y.: Mektebetü'l-Maârif, 1421/200), 334-335. Müellif bu tanımın Ebû Hayyân el-Endelûsî’ye ait olduğunu ifade etmektedir. 
çeşitli tefsir şekilleri bulunmaktadır. ${ }^{6}$ Kanun metnine verilecek mananın tespitine de yorum (tefsir, interpretation) denmiştir. ${ }^{7}$ Bu yüzden içtihat, aslında bir yorumlama/tefsir faaliyetidir. ${ }^{8}$ Kur'ân, Müslümanlar için şer'î delillerinin ilki olması hasebiyle çalışmamız için tefsirle kastedilen iki mana vardır. Bunlar "ilim olarak tefsir" ve "yorum anlamında tefsir"dir.

\subsection{Tahsis ve ta'mîm}

Tahsis kavrami; 'bir şeyi, diğerleri ona iştirak etmeyecek şekilde bütünden ayrı tutmak ${ }^{\prime 9}$ demektir. Bu manada tahsis, ta'mîmin yani genelleştirmenin zıddıdır. ${ }^{10}$ Usûl ilmindeki tanımıla, umûm ifade eden bir sözden, kapsamina giren bir ferdin veya fertlerin, hakikaten veya hükmen ayrı tutulmasıdır. ${ }^{11}$ Yine aynı manayı ifade etmek üzere, zihinde bir manayı tasavvur edip buna karşılık özel bir kelime ile tayin edilen lafızlara da hâs lafız denmiştir.12 فلبث فيهم ألف سنة إلاّ خمسين عاماً "Iclerinde elli yılı müstesna bin sene durdu."13 âyetinde olduğu gibi istisnâ, şart, (son sınırı ifade etme anlamında) gaye ve sıfat olmak üzere muttasıl; aklî, hissî ve sem'î şeklinde munfasıl olmak üzere iki tür tahsisin varlığından söz edilmiştir. Hüküm olarak da tahsisin âmma mukaddem olduğu söylenmiştir. ${ }^{14}$

\subsection{Lehve'l-hadis}

Sözlükte lehv, "oyun ve eğlence" demek olup insanın meşgul olduğu bir şey sebebiyle asıl başka bir şeyden gafil olması

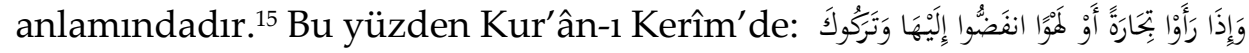
قَأئمًا yani "Onlar bir ticaret veya bir eğlence gördüklerinde, seni ayakta

6 Mehmet Erdoğan, Fıkıh ve Hukuk Terimleri Sözlüğ̈̈ (İstanbul: Ensar Yayınları, 2010), "Tahsis", 538.

7 Ferhat Koca, İslâm Hukuk Metodolojisinde Tahsis (Daraltıcı Yorum) (İstanbul: İSAM Yayınları, 2011), 36.

8 Ayrıntılı bilgi için bk. Koca, Tahsis, 21-44.

9 İbn Manzûr, Lisânü'l-'Arab (Beyrut: Dâru Sâdır, 1414), "ḩașașa", 7/24.

10 Ebu'l-Kâsım Hüseyin b. Muhammed b. el-Mufaddal er-Râgıb el-İsfahânî, el-Müfredât fì garîbi'l-Kur'ân, thk. Safvân Adnân ed-Dâvûdî (Dımaşk: ed-Dâru'ş-Şâmiyye, 1412), "ḩașșa", 284.

11 Erdoğan, "Tefsir", 558.

12 Koca, Tahsis, 49-50.

13 el-'Ankebût 29/14.

14 Bu konuda ayrıntılı bilgi için bk. Ebu'r-Rebî’ Süleymân b. Abdülkavî b. Abdülkerîm b. Saîd et-Tûfî, el-Iş̧ârâtü'l-ilâhiyye ile'l-mebâhisi'l-usûliyye, thk. Ebû Asım Hasan b. Kutb (Kâhire: el-Fâruku'1-Hadîsiyye, 1423/2002), 1/228-231.

15 İbn Manzûr, "lehv”, 15/259. 
402 | F. ARPAGUŞ / 'Lehve'1-Hadis'in Müziğe Tahsisinin Tefsir Açısından Değerlendirilmesi

bırakarak ona koşarlar."16 buyurulmuştur. Bir başka tanıma göre, lehvin kelime anlamından çok, hedef anlamının ön plana çıktığı, bu yüzden "insanı amacından uzaklaştıran meşguliyet"17 olarak tarif edildiği görülür. O halde "söz" manasındaki "hadis" kelimesine muzâf olan lehve'l-hadis terkibine, "sözün eğlendirici ve oyalayıcı olanı" ya da daha Türkçe ifadeyle (sıfat tamlaması şeklinde)- "boş, oyalayıcı ve eğlendirici söz" manasını vermek mümkündür. Bu durumda ومن الناس من âyetinin manası, insanlardan öylesi de vardır ki oyalayıcı ve eğlendirici (boş) sözü satın alır demek olur.

\subsection{Müzik ya da mûsikî}

Arapça; mûsikâ, mûsikî ve ğinâ kelimeleriyle ifade edilen müzik, bazı duygu ve düşünceleri düzenli ve ahenkli seslerle ifade etme sanatı ${ }^{18}$ diye tarif edilmiştir. Bir diğer tanıma göre duygu, düşünce, fikir veya herhangi bir durumu anlatmak için ölçülü ve ahenkli seslerin, ritimli veya ritimsiz, sanatsal olarak bir araya getirilmesidir. ${ }^{19}$ Fikhî bakış açısıyla yapılan bir diğer tanıma göre de mûsikî veya müzik (semâ' ve ğinâ), kadın veya erkek tarafından ses ve âlet (çalgı) ile icrâ edilen malûm san'atın bütün şubelerine şamildir ve hüküm bakımından bu şube ve şekiller arasında farklılık olup müziğin icrâ edildiği yer ve maksadın hükme tesiri söz konusudur. ${ }^{20}$ Tarifte, "malum sanatın ses unsuruyla icra edilen her türlüsü"ne yapılan vurgu bizce önemlidir. Çünkü birtakım nağmelerle okunan Kur'ân ve ezan gibi unsurlarda da bir mûsikî ortaya çıkmaktadır.

Müzik, düşünme özelliği dışında insanı diğer varlıklardan ayıran "hissiyât-1 âliyye" denilen hislerin başında gelmektedir. ${ }^{21}$ Hukemânın bu fennin kaidelerini ortaya koymadaki maksadı, eğlence olsun diye değil,

16 Kur'an-ı Kerim ve İzahlı Meali (Türkçe Anlamı), çev. Sadreddin Gümüş vd. (İstanbul: İpek Yayınları, 1997), el-Cum'a 62/11.

17 İsfahânî, el-Müfredât, "lehv", 748.

18 Erdoğan Ateş, Türk Din Mûsikîsi (İstanbul: Rağbet Yayınları, 2017), 21.

19 Ahmet Hakkı Turabi, "Mûsikî", Türk Din Mûsikîsi El Kitabı, ed. Ahmet Hakkı Turabi (Ankara: Grafiker Yayınları, 2017), 14.

20 Hayrettin Karaman, Günlük Hayatımızda Helaller ve Haramlar (İstanbul: İz Yayıncılık, 2008), 132-135.

${ }^{21}$ Mehmet Tıraşcı, “İslam'da Mûsikî”, Türk Din Mûsikîsi El Kitabı, ed. Ahmet Hakkı Turabi (Ankara: Grafiker Yayınları, 2017), 14. 
kudsî âlemle konuşan nefisleri, ruhlarla kaynaştırmak içindir.22 Bunu teyit babında Mevlevîlerin ney sazından çıan sese yüklediği anlam, kendisine ilâhî nefesin üflendiği insan-1 kâmili temsil etmektedir. ${ }^{23}$ Onların bu yaklaşımindan ونفختُ فيه من روحي "ona ruhumdan üfledim"24 ayetiyle irtibat kurdukları anlaşılmaktadır. ${ }^{25}$

\section{Hz. Peygamber devrinde müzik}

Muhammed Hamidullah (öl. 2002), Hz. Peygamber'in (a.s.) şiir ve mûsikî konusundaki tavrını resmederken önde gelen hadis âlimlerinden nakiller yapar ve şiir ve mûsikînin gerek müspet gerekse menfi yönüne işaret eder. Hikmet dolu şiirin insanı büyülediği ${ }^{26}$ rivâyetine yer verdikten sonra iman ve iyilik adına şiir söyleyen şairleri $\mathrm{Hz}$. Peygamber'in methettiğini, buna mukabil hayâsız şairleri de zemmettiğini belirtir. Onun bu konudaki değerlendirmesi ise şöyledir: Hz. Peygamber'e göre önemli olan, şiirin konusu ve kullanılış biçimidir. ${ }^{27}$

Hz. Peygamber (a.s.), şarkı ve mûsikî konusunda da benzer bir tutum sergilemiş; vazifelerin ihmali derecesine varan bu eğlence vasıtasına karşı katı davrandığı olmuştur. Ancak insanın tabi fıtratından kaynaklanan teğanni muharrikine set çekmemiş, hatta onu Kur'ân tilaveti gibi ulvî bir yöne sevk etmiştir. Öyle ki güzel ses ve mûsikî ile okunan Kur'ân'1, Davud peygamberin mezamirine mukayese etmiştir. ${ }^{28}$

Abdülhayy el-Kettânî (öl. 1962) de her yönüyle Hz. Peygamber'in (a.s.) yönetim şeklini incelediği et-Terâtibü'l-idâriyye adlı eserinde, mûsikîye genişçe yer ayırmıştır. Konumuz açısından Ebu'l-Ferec elIsfahâni' nin (öl. 356/967) rivâyet ettiği belirtilen şu hâdise manidardır:

“Rasûlullah (a.s.), Âtime'nin avlusundan geçerek Hassân b. Sâbit'e uğradı. O esnada

Hassân'ın yanında arkadaşı Simâtân ve kendilerine şarkı söyleyen cariyesi vardı.

22 Kâtib Çelebi (Hacı Halife), Keşfü'z-zunûn 'an esâmi'l-kütübi ve'l-funûn (Lübnan: Dâru'lKütübi'l-ìlmiyye, 1941), 2/1902.

23 Şefik Can, Konularına Göre Açıklamalı Mesnevî Tercümesi (İstanbul: Ötüken, 2011), 1/13.

24 el-Hicr 15/29.

25 Safi Arpaguş, “Neyin Sırrı: Kemâle Yolculuk”, Semazen (Erişim 25 Haziran 2020).

26 Ebû Abdillâh Muhammed b. İsmâîl b. İbrâhîm el-Cu'fî el-Buhârî, el-Edebü'l-müfred, thk. Semîr b. Emîn ez-Züheyrî (Riyad: Mektebetü'l-Meârif, 1419/1998), 334 (No. 344).

27 Muhammed Hamidullah, İslam Peygamberi, çev. Salih Tuğ (İstanbul: İrfan Yayıncılık ve Ticaret, 1993), 2/748-749.

28 Hamidullah, İslam Peygamberi, 2/749. 
404 | F. ARPAGUŞ / 'Lehve'1-Hadis'in Müziğe Tahsisinin Tefsir Açısından Değerlendirilmesi

Cariye: 'Bu şekilde şarkı söylememde bir sakınca var mı?' diye sorduğunda Rasûlullâh güldü ve: Sakınca yok, buyurdu."29

Yukarıda anlatılan olayda cariyenin nasıl bir şarkı söylediği ve Hz. Peygamber'in (a.s.) neye cevaz verdiğinin ayrıntısı yoktur. Müellif, cariyenin adının Sîrîn olduğunu, hadisin bir benzerinin de İbn Abbâs'a isnad edilerek İbn Vehb (öl. 197/813) tarafından rivâyet edildiğini söyledikten sonra İbn Kuteybe (öl. 276/889), Ebû Mansûr et-Temîmî (öl. ?), İbn Hazm (öl. 456/1064) ve Hafız Ebûbekr Muhammed b. Abdullah el-'Âmirî (öl. ?) gibi zevatın sema' ve müzik hakkında eser telif ettiğini dile getirir. ${ }^{30}$ Bir fikir vermesi bakımından kitabın mûsikîye ayrılan bölümündeki bazı başlıklar ise şu şekildedir: Hz. Peygamber zamanında Medine'deki şarkıcılar, düğün yemeğinde şarkı söylenmesi, seleften mûsikî ilmine önem veren kimseler ve sahabeden müzik dinleyenler, Hz. Âişe'nin Rasûlullah'ın yanında müzik dinlemek için izin istemesi, Habeşlilerin Mescid-i Nebî'de raksı, düğün evine gelenlerin söylediklerinin dinlenilmesi. ${ }^{31}$ Bütün bunlardan çıaracağımız sonuç ise Rasûlullah'ın hayatında mûsikînin tabi bir şekilde var olduğudur. Ancak genel hatları ile ortaya konan bu tutumun ayrıntısına inildiğinde orada müziğin helalliği, haramlığı ve bu ikisi arasında hükmünün ne olacağı konusunda pek çok tartışmanın yapıldığı bir gerçektir. Kısaca ifade etmek gerekirse sözlerinde küfür, isyan, cinsellik gibi İslâm'ın hoş karşılamadığı ve vakit israfına sebep olmayan müziğin caiz olduğu söylenmiş; ama yine de bunu bir takva meselesi haline getiren kimseye de saygı gösterilmesi gerektiği ifade edilmiştir. ${ }^{32}$

\section{Kaynaklarda lehve'l-hadis}

\subsection{Klasik hadis kaynaklarında lehve'l-hadis}

Klasik hadis kaynakları tarandığında Ahmed b. Hanbel'in (öl. 241/855) Müsned'inde, ${ }^{33}$ Buhârî'nin (öl. 256/870) el-Edebü'l-müfred'inde, ${ }^{34}$

29 Muhammed Abdülhayy b. Abdilkebîr b. Muhammed el-Hasenî el-İdrîsî el-Kettânî, et-Terâtibü'l-idâriyye, thk. Abdullah el-Hâlidî (Beyrut: Şeriketü Dâri'l-Erkâm, 2008), 2/86. Ayrıca müellif bu hadiseyi İbn Abdi Rabbih'in el-ïkdü'l-ferî̀ adlı eserinde zikrettiğini ifade eder.

30 Kettânî, et-Terâtibü'l-idâriyye, 2/86.

31 Kettânî, et-Teratibü'l-idâriyye, 2/79-92.

32 Muhsin Demirci, Kur'ân Tefsirinde Farklı Yorumlar (İstanbul: İfav Yayınları, 2017), $2 / 539$.

33 Ebû Abdillâh Ahmed b. Muhammed b. Hanbel eş-Şeybânî, Müsned, thk. Şuayb elArnaût vd. (Dımeşk: Müessesetü'r-Risâle, 1421/2001), 36/611 (No: 22280). 
Fâkihî'nin (öl. 272/891-892 [?]) Ahbâru Mekke'sinde, ${ }^{35}$ Tirmizî'nin (öl. 279/892) Sünen'inde, ${ }^{36}$ İbn Ebî Üsâme'nin (öl. 282/895) Buğyetü'lbâhis'inde, ${ }^{37}$ Taberânî'nin (öl. 360/971) el-Mu'cemü'l-kebîr'inde ${ }^{38}$ ve daha pek çok hadis kitabında Lokmân sûresi 6. âyetteki lehve'l-hadis tabiri ile ğinâ yani müzik arasında irtibat kurdukları görülür. Onların bu âyetle irtibat kurmaları, Ahmed b. Hanbel'in Müsned'inde geçtiği şekliyle, Ubeydullah b. Zahr, Ali b. Yezid, Kâsım ve Ebû Ümâme tarîkiyle Hz. Peygamber'e (a.s.) isnad edilen: "Şarkıcı kadınları alıp satmayın. (Şarkı söylemeleri için) onlarn eğitmeyin. Bunların ticaretinde bereket olmadığı gibi kazançları da haram kılınmıştır."39 hadisi sebebiyledir. Tirmizî de aynı tarikle ve neredeyse aynı lafızlarla hadisi naklettikten sonra "lehve'lhadis" âyetinin bu ve benzeri şeyler sebebiyle nazil olduğunun söylendiğini dile getirmektedir. ${ }^{40}$ Lafız farklılıklarıyla da olsa İbn Ebî Üsâme'nin Buğyetü'l-bâhis ve Taberânî'nin el-Mu'cemü'l-kebîr'indeki rivâyetlerle Ahmed b. Hanbel ve Tirmizî'nin rivâyetleri birbirine çok benzemektedir. ${ }^{41}$ Fâkihî’ye gelince; o, ومن الناس من يشتري لهو الحديث âyetinin sebeb-i nüzulüyle alakalı şöyle bir olay anlatmaktadır:

“Kureyş, sadece bedevîlerin yaptığı gibi birtakım şeylere vurarak şarkı söylemesini bilirdi. Fakat ne zaman ki Nadr b. Hâris, Kisra'ya gitti; işte o zaman uğradığı Hîre'de

34 Buhârî, el-Edebü'l-müfred, 421 (No. 786).

35 Ebû Abdillâh Muhammed b. İshâk b. Abbâs el-Fâkihî, Ahbâru Mekke, thk. Abdülmelik Abdullah Düheyş (Beyrut: Dâru Hıdr, 1414), 3/10 (No: 1739).

36 Ebû Îsâ Muhammed b. Îsâ b. Sevre et-Tirmizî, el-Câmi'u'l-kebîr = Sünen, thk. Beşşâr Avvâd Maruf (Beyrut: Dâru'l-Garbi'l-İslâmî, 1998), "Tefsir", 32 (No: 3195).

37 Ebû Muhammed el-Hâris b. Muhammed el-Bağdâdî, Buğyetü'l-bâhis 'an zevâidi Müsnedi'l-Hâris, thk. Hüseyin Ahmed Salih el-Bâkirî (Medine: Merkezü Hidmeti'sSünne ve's-Sîreti'n-Nebeviyye, 1413/1992), 2/843 (No. 892).

38 Ebu'l-Kâsım Müsnidü'd-dünyâ Süleymân b. Ahmed et-Taberânî, el-Mu'cemü'l-kebîr, thk. Hamdi b. Abdülmecîd es-Selefî (Kahire: Mektebetü İbn Teymiye, 1415/1995), $8 / 180$ (No. 7749).

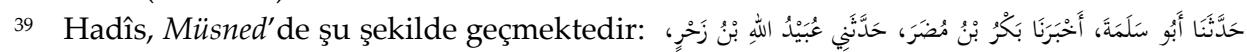

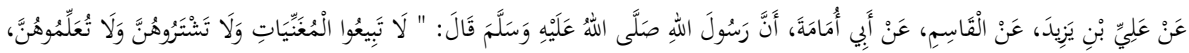

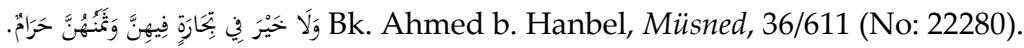

40 Tirmizî́deki rivayette sadece المغنيّات kelimesi yerine onunla aynı anlamda القينيات kelimesi kullanılmıştır. Ayrıntılı bilgi için bk. Tirmizî, Sünen, “Tefsir”, 32 (No: 3195).

41 Bk. İbn Ebî Üsâme, Bư̆getü'l-bâhis, 2/843 (No. 892); Taberânî, el-Mu'cemü'l-kebîr, 8/180 (No. 7749). 
406 I F. ARPAGUŞ / 'Lehve'l-Hadis'in Müziğge Tahsisinin Tefsir Açısından Değerlendirilmesi

barbat adında vurmalı bir çalgıyı öğrendi. Sonra insanlara bu şekilde şarkı söyledi ve Mekkeliler'e de bunu öğretti. Bunun üzerine 'lehve'l-hadis' âyeti nazil oldu.”42

Tüm bunlardan farklı olarak Buhârî, Sahîh'inde âyeti daha geniş perspektifte anladığını ima ederek "Allah yolundan insanı alıkoyan her şeyin batıl olduğu babı"nda ومن الناس من يشتري âyetini zikretmiş̧;3 fakat el-Edebü'l-müfred'inde âyetteki lehve'l-hadisi İbn Abbâs'ın mevkuf bir rivâyetle de olsa müzik ve benzeri şeyler olarak tefsir ettiğini belirtmiştir. ${ }^{44}$

Muhaddislerin hadisi nasıl değerlendirdiği sorusuna gelince; Şuayb el-Arnaût (öl. 2016) başkanlığında Müsned' in tahkikini yapanlara göre, hadisin senedinde bulunan Ubeydullah b. Zahr, Ali İbn Yezîd ve Ebû Seleme gibi kimseler, hadis kritiği açısından zayıf kimseler olarak görülmüştür. ${ }^{45}$ Tirmizî de hadisin râvîlerinden özellikle Ali b. Yezîd'in zayıf olduğunu ifade etmiştir. ${ }^{46}$

\subsection{Klasik tefsir kaynaklarında lehve'l-hadis}

Tâbiîn dönemi müfessirlerinden Mücâhid (öl. 103/721), yukarıda bahsi geçen hadisi zikretmemiş; fakat bir rivâyet silsilesi verdikten sonra onlardan nakille lehve'l-hadisi erkek ve kadın şarkıcıları, çok mal karşılığında satın almak, onları dinlemek ve benzeri boş şeylere harcama yapmak olarak tarif etmiştir. ${ }^{47}$ Mukâtil b. Süleymân (öl. 150/767) ise Fâkihî'nin Nadr b. Haris rivâyetini farklı bir şekilde işlemiştir. Nadr, tüccar olarak Hîre' de bulunduğu sırada, İran'ın eski hükümdarlarından Rüstem ve İsfendibâz'ın sözlerini ücret ödeyerek satın almış, Mekke'ye geldiğinde: “Muhammed size, işte şu Rüstem'in sözündeki gibi Âd ve Semûd kavminden bahsediyor." diyerek hem Kur'ân'ın orijinal olmadığını söylemeye çalışmış hem de Kur'ân'la alay etmiştir. ${ }^{48}$ Süfyân es-Sevrî (öl. 161/778), İbn Vehb ve Yahya b. Sellâm (öl. 200/815) da

42 Fâkihî, Ahbâru Mekke, 3/10 (No: 1739).

43 Ebû Abdillâh Muhammed b. İsmâîl b. İbrâhîm el-Cu'fî el-Buhârî, Sahîhu'l-Buhârî, thk. Muhammed Züheyr b. Nasr (b.y.: Dâru Tavki'n-Necât, 1422), “İsti'zân”, 66.

44 Buhârî, el-Edebü'l-müfred, 421 (No. 786).

45 Ahmed b. Hanbel eş-Şeybânî, Müsned, 36/611-2 (No: 22280).

46 Tirmizî̀, "Tefsir”, 32 (No. 3195).

47 Ebu'l-Haccâc Mücâhid b. Cebr et-Tâbiî el-Mekkî el-Kuraşî el-Mahzûmî, Tefsîru Mücâhid, thk. Muhammed Abdüsselâm Ebu'n-Nîl (Mısır: Dâru'l-Fikri'l-İslâmî, 1410/1980), 1/541.

48 Ebu'l-Hasen Mukâtil b. Süleymân el-Ezdî el-Belhî, Tefsîru Mukâtil b. Süleymân, thk. Abdullah Mahmûd Şehhâte (Beyrut: Dâru İhyâi't-Türâs, 1423), 3/432. 
lehve'l-hadisin ğinâ/müzik olarak tefsir edildiğini Mücahid'den nakille dile getirmiş; fakat Yahya b. Sellâm, Sevrî ve İbn Vehb'den farklı olarak ayrıca lehve'l-hadisle kastedilenin "şirk" olduğunu söylemiştir. ${ }^{49}$ Abdürrezzâk es-San'ânî (öl. 211/826-27) ise Sevrî ve Mücahid kanalıyla lehve'l-hadisin müzik olduğunu belirttikten sonra oyun ve boş işlere dair her şey olduğu kaydını ekleyerek daha önceki iki görüşü cem etmeye çalışmıştır.

Taberî̀nin (öl. 310/923) yaklaşımina gelince; o, “Cenâb-1 Hakk'ın kavlinin te'vîli" başliğ1 altında, tevil ehlinin âyet hakkında ihtilaf ettiğini belirttikten sonra buraya kadar yukarıda verdiğimiz görüşlerin tamamını, hatta daha fazlasını zikretmiştir. Ayrıca o, âyetteki iştirâ'/إِّرآ kelimesini “istihbâb" olarak anladığını, buna göre de mananın, hak söze karşı boş ve batıl sözleri tercih etmek olduğunu dile getirmiştir. Kendi görüşünü, hemen devamındaki "Ona âyetlerimiz okunduğu zaman sanki onları hiç işitmemiş, sanki kulaklarında ă̆ırlık varmış gibi büyüklük taslayarak yüz çevirir." 50 âyetiyle irtibat kurarak açıklayan Taberî, burada kendilerinden bahsedilenlerin Müslümanlar olmadığını dile getirdikten sonra bu konuda doğru olanın şöyle söylenmesi olduğunu ifade etmiştir:

“Bununla kastedilen, Allah ve Rasûlünün dinlenmesini yasak ettiği ve Allah'ın yolundan alıkoyan bütün oyalayıcı sözlerdir. Çünkü Allah Teâlâ lehve'l-hadisi tahsis etmemiştir. Âyet; şirk, Allah yolundan alıkoyan müzik ve buna benzer hususi şeyleri de kapsayacak şekilde umûm üzere gelmiştir." ${ }^{51}$

Bu konuda İbn Kesîr'in (öl. 774/1373) görüşüne de yer vermek istiyoruz. O, söz konusu ayetin tefsirinde, ilgili rivâyetlerden sonra hadisin râvîleri ve sıhhati hakkında şu değerlendirmeyi yapmıştır:

“Tirmizî ve Taberî, 'şarkıcı kadınların alınıp satılması' hadisini ve benzerlerini rivâyet etmiştir. Tirmizî, râvîlerden Ali b. Yezid'in zayıf, hadisin de garib olduğunu ifade

49 Bk. Ebû Abdillâh Süfyân b. Saîd b. Mesrûk es-Sevrî, Tefsîru's-Sevrî (Beyrut: Dâru'1Kütübi'l-İlmiyye, 1403/1983), 1/238; Ebû Muhammed Abdullah b. Vehb b. Müslim elMisrî el-Kureşî, Tefsîru'l-Kur'ân, thk. Miklos Morânî (b.y.: Dâru'l-Garbi'l-İslâmî, 2003), 1/52; Yahyâ b. Sellâm b. Ebî Sa'lebe et-Teymî el-Kayrevânî, Tefsîru Yahya b. Sellâm, thk. Hind Şelebî (Beyrut: Dâru'l-Kütübi'l-İlmiyye, 1425/2004), 2/669-670.

50 Lokmân 31/7.

51 Ebû Ca'fer Muhammed b. Cerîr b. Yezîd el-Âmülî et-Taberî, Câmi'u'l-beyân fî te'vîli'lKur'ân, thk. Ahmed Muhammed Şâkir (b.y.: Müessesetü'r-Risâle, 1420/2000), 20/126130. 
etmiştir. Ben de derim ki: Gerek Ali gerek hocası gerek kendisinden rivâyet eden kişinin hepsi zayıf kimselerdir. Doğrusunu en iyi Allah bilir." 52

Onun bu yaklaşımından sonra çalışmamız için şu ayrımın yapılması, bizim için önemlidir. Her ne kadar hadis tenkidi açısından senet ve sıhhat yönüyle bu ve benzer lafızlarla rivâyet edilen hadisler problemli olsa dahi şarkıcı kadınların alınıp satılması ve onlar üzerinden kazanç temin edilmeye çalışılması, kötü bir iştir. Böyle bir teşebbüs, ahlakî olmadığı gibi dinî de değildir. Fakat senedinde ve sıhhatinde problem olan bu hadisin, bir şekilde irtibat kurularak "lehve'l-hadis" $i$ tahsis ettiği gibi ciddi bir iddiada bulunmak da doğru değildir. O halde zayıf ve garip olmasına rağmen hadisin manaca dinin özüne uygun; fakat âyetle kurulan münasebet açısından (âyeti tahsis ettiği hükmü verilmesinin ise) yanlış olduğu belirtilmelidir.

\subsection{Klasik fıkıh kaynaklarında lehve'l-hadis}

İmam Muhammed'in (öl. 189/805) Siyer-i kebîr'inde bahsettiğine göre Enes b. Malik (r.a.), şarkı söyleyen kardeşi Berâ'nın yanına gitmiştir. Berâ'nın bu konudaki delili, bir insanın kendi duyacak kadar hoşlandığı şeyi söylemesinde herhangi bir beis olmadığına dair sözdür. Ama başkasının duyması ve hoşlanması, mekruh sayılmıştır. Hz. Peygamber'in: "Nikâhı defle de olsa ilan edin!"53 sözü sebebiyle, lehviyât türünden de olsa dügünde def çalmakta ve kafiyeli nazımlarla şarkı söylemekte bir beis görülmemiştir. ${ }^{54}$ Serahsî'ye (öl. 483/1090[?]) göre lehviyâttan olduğu için bu da mekruhtur. Hanefî fukahâsı bu konuda ومن âyetinin zâhirini delil kabul etmiştir. Çünkü âyette yer alan lehve'l-hadis, ğinâ yani müzik olarak tefsir edilmiştir. Berâ'nın meselesine gelince; onun söylediği, içerisinde nasihat ve hikmet olan şiirdir. Eğer şiir, mübah olan sözler üzerine inşa edilirse onu söylemekte herhangi bir beis yoktur. Ancak, mesela bir kadının kaşını gözünü

52 Ebü'l-Fidâ' İmâdüddîn İsmâîl b. Şihâbiddîn Ömer b. Kesîr b. Dav' b. Kesîr el-Kaysî el-Kureşî, Tefsîru'l-Kur'âni'l-'azîm, thk. Sâmî b. Muhammed Sellâme (b.y.: Dâru Tayyibe li'n-Neşr, 1420/1999), 6/331.

53 Ebûbekr Ahmed b. Amr Abdilhâlik el-Bezzâr, Müsnedü'l-Bezzâr = el-Bahru'z-zehhâr, thk. Mahfûzu'r-Rahmân Zeynullah (Medine: Mektebetü'l-Ulûm ve'l-Hikem, 1988), 6/170 (No. 2214).

54 Ebû Muhammed (Ebu's-Senâ) Bedrüddin Mahmûd b. Ahmed b. Mûsâ b. Ahmed elAynî, el-Binâye şerhu'l-Hidâye (Beyrut: Dâru'l-Kütübi'l-İlmiyye, 1420/2000), 12/89; İbn Âbidîn Muhammed Emîn b. Ömer b. Abdülaziz ed-Dımeşkî el-Hanefî, Reddü'lmuhtâr (Beyrut: Daru'l-Fikr, 1412/1992), 6/424. 
methederse, bu mekruh sayılmıştır. Semerkant ahalisinin fetvalarında da vurmalı çalgıyla söylenen şarkıyı dinlemenin haram olduğu hükmü vardır. Onların bu konudaki delili, Hz. Peygamber'in (a.s.) şu hadisidir: “Oyalayıp eğlendirici şeyleri dinlemek günahtır. Böyle yerlerde oturmak fisk, bundan lezzet almak ise küfürdür."55 Yine Hanefîlerin meşhur kitaplarından Hidâye şerhi Binâye ve İbn Âbidîn'in (öl. 1252/1856) Reddü'l-muhtâr' inda, yukarıdaki bilgilerin hemen hemen benzeri bilgiler yer almaktadır. ${ }^{56}$

Hadis kaynaklarında lehve'l-hadis konusu işlenirken Ahmed b. Hanbel'in nakillerine daha önce yer verildiğinden burada onu tekrar etmeye ihtiyaç yoktur. Birer örnekle de olsa diğer mezheplerin yaklaşımına gelince; Şâfiî fıkhını derleyen el-Hâvi'l-kebîr'de ve Mâlikî fakih İbn Rüşd'ün (öl. 520/1126) el-Beyân ve't-tahsîl'inde lehve'l-hadis konusu ele alınırken, sözün ya müzik ve eğlenceye veya müzik aletlerine getirildiğini söylemenin yeterli olacağı kanaatindeyiz. ${ }^{57}$ Bütün bu veriler bize, aslında lehve'l-hadisin müziğe tahsis edildiğinin açık ve somut delilleridir.

\subsection{Günümüz ilahiyat araştırmalarında lehve'l-hadis}

Günümüz ilahiyat araştırmalarında lehve'l-hadis âyetine genelde fıkıh, tefsir, tasavvuf ve dinî mûsikî alanındaki araştırmacıların yer verdiği görülmektedir. Bu araştırmalardan birine göre lehv, Kur'ân-1 Kerim'de sadece bir yerde hadis kelimesine izafetle lehve'l-hadis şeklinde kullanılmış, ne olduğu konusunda ise şirk, davul, sihir, Allah'a ibadetten alıkoyan şeyler, hurafe ve çalgılar gibi daha başka yorumlar yapılmıştır. Âyetin -yukarıda söz konusu edilen- Nadr b. Hâris hadisesi yanında, Kureyşli bir adamın şarkıcı bir cariye satın alarak bununla

55 Bu hadis Ebû'l-Me'âlî’nin el-Muhît'inde استماع الملاهي معصية والجلوس عليها فسق والتلذذ بها من الكفر lafızlarıyla senetsiz olarak verilmektedir. Fakat hadis kitaplarında böyle bir hadise rastlanamamıştır. Bu konuda ayrıntılı bilgi için bk. Ebu'l-Me'âlî Burhânüddîn Mahmûd b. Ahmed b. Abdülazîz b. Ömer b. Mâze el-Buhârî, el-Muhîtu'l-burhânî fî fikhı'n-Nu'mânî, thk. Abdülkerim Sâmî el-Cündî (Beyrut: Dâru'l-Kütübi'l-İlmiyye, 1424/2004), 5/369.

56 Aynî, el-Binâye, 6/424.

57 Ayrıntılı bilgi için bk. Ebu'l-Hasen Ali b. Muhammed b. Muhammed b. Hubeyb elBasrî el-Bağdâdî, el-Hâvi'l-kebîr, thk. eş-Şeyh Ali Muhammed Muavvad - eş-Şeyh Âdil Ahmed (Beyrut: Dâru'l-Kütübi'l-İlmiyye, 1419/1999), 17/190; Ebu'l-Velîd Muhammed b. Ahmed b. Rüşd el-Kurtubî, el-Beyân ve't-tahsîl, thk. Muhammed Hacî vd. (Beyrut: Dâru'l-Garbi'l-İslâmî, 1408/1988), 18/541. 
410 I F. ARPAGUŞ / 'Lehve'1-Hadis'in Müziğe Tahsisinin Tefsir Açısından Değerlendirilmesi

insanları eğlendirdiği ve böylelikle insanların Hz. Peygamber'i (a.s.) dinlemekten yüz çevirmesi üzerine nazil olduğu rivâyetine yer verilmiştir. $^{58}$

Diğer bir çalışmaya göre, “İslam fıkhında müzikle ilgili yaklaşımlar" başlı̆̆ı altında müziğe yasaklayıcı yaklaşım sergileyenlerin delilleri sayılırken Lokmân sûresi 6 . âyetin delil olarak getirildiği zikredilmiş, bu görüşte olanlara göre lehve'l-hadisten maksadın şark1 olduğu ifade edilmiştir. ${ }^{99}$ Bir diğerinde ise sahabe, tabiîn ve tebe' $u^{\prime} t$ tâbiînden yapılan nakillere yer verildikten sonra onların lehve'l-hadis terkibinin içeriğini iki farklı anlamda doldurduğu belirtilmiştir. Bunlardan birinci grupta yer alanlara göre boş ve insanları yoldan çıkaran asılsız her türlü konuşma ve anlatı olduğu, ${ }^{60}$ diğerlerine göre ise şarkı-türkü ya da daha genel manada müzik olduğu ifade edilmiştir. ${ }^{61}$ Bunlar içerisinde en keskin görüş ise "müziğin ve müzik aleti çalmanın haram olduğu konusunda icma'ın olduğunu"62 söyleyenlerdir. Ancak eğer bir icma'dan söz edilecekse, Hz. Peygamber'in (a.s.) hayatı da buna dâhil olmak üzere, tarihin hiçbir devrinde insanlığın Allah'ın insan fıtratına yerleştirdiği müzikten müstağni kalamadığından bahsedilmelidir. Nitekim Hz. Ömer (r.a.), bayram günü müzik icra edenleri tehdit ettiğinde Hz. Peygamber (a.s.) ona mâni olmuş, mescidinde Habeşlilerin raks etmesine müsaade etmiş, düğün merasimlerinin de neşe ve eğlenceden mahrum bırakılmaması gerektiğini tavsiye etmiştir. ${ }^{63}$

Müzik için hem lehte hem de aleyhte delilleri zikreden diğer çalışmalarda da âyetin, müziğin yasaklığ 1 için delil getirildiğini ifade

58 Pehlül Düzenli, “Klasik İslâm Kaynaklarında Müzik Tartışmaları”, Marife 1/2 (Aralık 2001), 44.

59 Yasin Kurban, “İnsan Tabiatı ve İslam Açısından Müzik (Müzik-Fıtrat İlişkisi)”, Atatürk Üniversitesi Sosyal Bilimler Enstitüsü Dergisi 23/1 (Mart 20199, 27.

60 Mukadder Arif Yüksel, “Kur'ân'da Hadîs Kelimesinin Semantik Anlamı”, Bozok Üniversitesitesi İlahiyat Fakültesi Dergisi [BOZIFDER] 6/2 (Temmuz-Aralık 2017), 144146.

61 Demirci, Kur'ân Tefsirinde Farklı Yorumlar, 2/537.

62 Halil Gönenç, el-Müntehabâtü'l-fikhiyye el-muasıra (İstanbul: el-Mektebetü'l-Hanefiyye, ts.), 287; Şinasi Kaya, Ne Ifrat Ne Tefrit Musıkî Hakkında Tam Tespit (Samsun: y.y., 1993), 63.

63 Hamidullah, İslâm Peygamberi, 749-750. 
edenler görülmektedir. ${ }^{64} \mathrm{Bu}$ bilgilerden hareketle, günümüz ilahiyat araştırmacılarından çoğunun lehve'l-hadisi, tahsis üzere dar manada müzik olarak anladıkları; ama buna rağmen müziğe yaklaşımlarının bütünüyle menfi olmadığı anlaşılmaktadır. Onlara göre eğitim ve tedavi ${ }^{65}$ yanında insana faydası olan müzik, İslam âlimlerince helal kabul edilmiş ${ }^{66}$ ve medeniyet iddiasındaki Müslümanların diğer sanat dallarıyla birlikte, İsl'am'ın ruhuna uygun müzik eserleri ortaya koymalarının bir gereklilik olduğu belirtilmiştir. ${ }^{67}$ Müziğin hükmünün ne olacağı konusunda şu tespitin yapılmış olması ise son derece önemlidir:
“Bazı müellifler, az sayıdaki istisnalar dışında İslâm âlimlerinin ğinâyı kerih (haram veya mekruh) görme hususunda fikir birliği içinde olduğunu ifade ederken bazıları, içlerinde sahâbe ve tâbiîn âlimleriyle mezhep imamlarının da bulunduğu birçok kişinin semâı mubah saydığını belirtir ve onlardan ğinâ dinleyenlerin isimlerini verir. Ekollerden ve aynı ekole mensup âlimlerden farklı görüşlerin ve çelişkili rivayetlerin aktarılmış olması, lehte ve aleyhteki görüşlerin âyet ve hadislerle ve selef uygulamasıyla desteklenmesi, ayrıca ğinânın çalgı eşliğinde olup olmamasına ve kullanılan çalgının türüne göre farklı değerlendirmelerin yapılması, bu konuda kesin bir sonuca ulaşmayı zorlaştırmaktadır." 68

\subsection{Değerlendirme}

Buraya kadar aktarılan verilerden hareketle, söz konusu hipotezlerden hangisinin en isabetli teoriyi ortaya koyduğu, önem arz

${ }^{64}$ Ayrıntılı bilgi için bk. Bayram Akdoğan, “Bazı Âyet ve Hadisler Doğrultusunda, İslâm Açısından Mûsikî Sanatının Değerlendirilmesi", Ankara Üniversitesi İlahiyat Fakültesi Dergisi 39/1 (1999), 385-386; Sümeyra Güvendi, Fıkıhda Lehv (Oyun ve Ĕ̆lence) (Konya: Selçuk Üniversitesi, Sosyal Bilimler Enstitüsü, Yüksek Lisans Tezi, 2008), 51.

65 Mehmet Ayas, "Sema ve Devran Ritüellerinin Tasavvufî Eğitimdeki Yeri ve Mûsikî'nin Din Eğitiminde Değerlendirilmesi", Kilis 7 Aralık Üniversitesi Sosyal Bilimler Dergisi 8/15 (Haziran 2018), 32-33.

66 Düzenli, "Klasik İslâm Kaynaklarında Müzik Tartışmaları”, 58.

${ }_{67}$ Kurban, "İnsan Tabiatı ve İslam Açısından Müzik (Müzik-Fıtrat İlişkisi)”, 34. Ayrıca bk. Necdet Çağıl, "Kutsal Metinler ve Müzik", Atatürk Üniversitesi İlahiyat Fakültesi Dergisi 39 (2013), 1-46; Ahmet İnanır, “XVI. Yüzyıl Osmanlı Fakih ve Sûfîlerinin Semâ, Raks ve Devrân Tartışmalarında Lehte ve Aleyhte Kullandıkları Hukûki Deliller ve Değerlendirilmesi", Cumhuriyet Üniversitesi İlahiyat Fakültesi Dergisi 17/2 (Aralık 2013), 237-269.

68 Yunus Apaydın, "Mûsikî", Türkiye Diyanet Vakfı İslam Ansiklopedisi (İstanbul: TDV Yayınları, 2006), 31/261. 
etmektedir: Onu müziğe tahsis ederek âyetin manasını daraltan çoğunluğun görüşü mü? Yoksa -rivâyetlere rağmen- âyeti umûm üzere alıp daha geniş perspektifte değerlendiren diğer görüş mü? Kavramlardan başlayarak bir değerlendirme yapacak olursak şunları söylemek mümkündür:

Tefsir, ne sadece bir ilim ne de sadece bir yorum faaliyetidir. $\mathrm{O}$, ıstılâhî manada dini ilimlerden Kur'ân'ı yorumlama faaliyetinin adı iken diğer taraftan kanun metnine verilecek manayı tespit etme işlemidir. Müslümanlar için bu metin, Kur'ân-1 Kerîm'dir ve Kur'ân, şer'î delillerin ilkidir. Bu durumda müfessir, kanun koyucunun iradesine uygun olarak, insanların refahı için, onun herhangi bir şeyi unutmadığını varsayarak, değişen hayat şartlarına göre kanunu yorumlayan kimse olmaktadır. ${ }^{69} \mathrm{Bu}$ durumda tefsir ve içtihadın aynı noktada birleştiğini söylemek mümkündür.

Kur'ân'da içki, kumar, faiz ve daha başka şeylerin yasaklandığına dair delaleti kat'î hükümler varken, müziğin yasaklandığına dair bir hüküm yoktur. Aslında bu, müzik konusunda Müslüman toplum için bir genişlik sağlandığının da göstergesi olarak düşünülebilir. Fakat bazı İslam hukukçuları, şerî̀ delillerin ikincisi olan hadislerde, şarkıcı kadınların alınıp satılması, şarkı söylemeleri için eğitilmelerinin yasaklanmasıyla, senedinde problem olmasına ve birbirinden farklı sebeb-i nüzûl rivâyetlerine rağmen ومن الناس من يشتري âyetinin, müziği yasaklamak için nazil olduğu rivâyetini birleştirerek -belki dedelillerini, Kur'ânî bir dayanakla daha kuvvetli göstermek istemişlerdir. Oysa fakihlerin hepsi aynı düşünmemektedir. Mesela İmam Şâfiî̀'nin ğinâyı mübah gördüğ̈̈70 ve bazı Şafiî âlimlerin mendub addettikleri, Hanefi meşâyihinden ${ }^{71}$ ve Hanbeli fukahasından bazılarının mutlak manada onu mübah saydığı, Medineli âlimlerin bu konuda kısmen

69 Koca, Tahsis, 31.

70 Şafîi’nin, Kur'ân'ı güzel sesle okumaya müspet yaklaşımıyla, müziği meslek edinip buradan kendisine kazanç temin eden kimsenin şahitliğinin kabul edilmesi konusundaki yaklaşımı birbirinden farklıdır. Ayrıntılı bilgi için bk. Ebû Abdillâh Muhammed b. İdrîs b. Abbâs eş-Şâfiî, el-Ümm (Beyrut: Dâru'l-Marife, 1410/1990), $6 / 226$.

71 Ebû Hanîfe'ye göre, bir kimsenin müzik öğrettiği için ücret alması caiz değildir. Öğrencilerinden Ebû Yusuf ve İmam Muhammed de aynı görüştedir. Ayrıntılı bilgi için bk. Ebû Abdillâh Muhammed b. el-Hasen b. Ferkad eş-Şeybânî, el-Asl, thk. Muhammed Boynukalın (Beyrut: Dâru İbn Hazm, 1433/2012), 4/20. 
ılımlı düşündükleri ve Zâhilerin ğinâ ve müzik aletlerinden yararlanmanın mübahlığına hükmettikleri vâkidir.72 Durum bu iken lehve'l-hadisi ğinâya tahsis etmiş olmak, Kur'ân'1 kendi bütünselliğinden kopararak, âyetin, sadece bu meselenin hükmünü vaz' etmek için nazil olduğunu iddia etmektir ki bu, bir bağlam çerçevesinde konuşan insanın söylediklerinin sadece bir kısmını almaya benzemektedir.

Onların yaklaşımıyla, eldeki veriler delil kabul edilip görüşleri benimsenebilir ve doğrudan lehve'l-hadisin müziği tahsis ettiği söylenebilirdi. Ancak bu, tamamen bir yorumdan ibarettir ve lehve'lhadisin mûsikîyi hedef aldığ 1 kesin değildir. ${ }^{73}$ Böyle bir yorum, isabetli olabileceği gibi hatalı da olabilir. Hatta "insanlardan bir kısmı/bazıs1/öylesi de vardır ki" şeklinde tercüme edilen ومن الناس ifadesini dikkate alarak, Allah yolundan alıkoymak için lehve'l-hadisi satın alan kimseleri ifade etmesi bakımından hususi; fakat bu eylemi işleyen bütün fertleri kapsaması bakımından âyetin umûmî olduğunu söylemek, bizce daha isabetlidir. O halde:

1. Kur'ân'da içki, faiz ve kumarın yasaklandığı gibi müziğin de kesin olarak yasaklandığına dair herhangi bir delilin olmadığı,

2. Lehve'l-hadis ile şarkıcı kadınlar ve çalgı aletleri hakkında varid olan eserlerin birbiriyle kısmen örtüşse de mutlak manada örtüşmediği,

3. Lehve'l-hadisin müzik olarak tefsir ve tahsis edilmesinin, isabetli ya da hatalı bir yorum/ictihad olacağı hususları, açıklık kazanmış olmaktadır.

Sonuç olarak bu meselede ibrenin hangi yönü işaret ettiğini görebilmek için daha başka izahlara ihtiyaç vardır. Örneğin Kur'ân'1 kendi bağlamında, siyak/sibak ve sûrenin kendi bütünlüğü içerisinde değerlendirmek, bize başka bir perspektif sunabilir. Buna göre Lokmân sûresi, bütünüyle ihtiva ettiği konu bakımından iyilerle kötüleri ayrıştıran, mucize isteyenlere karşı Allah'ın âyetlerini işaret eden Mekkî sûrelerdendir. ${ }^{74}$ Başından itibaren; söylenenlerin, hikmetli kitabın âyetleri olduğu, ${ }^{75}$ namaz kılmak, zekât vermek ve ahirete de kesinkes inanmak suretiyle hidayete ve kurtuluşa ermiş iyi kimseler için bu

72 Apaydın, “Mûsikî”, 261.

73 Karaman, Helaller ve Haramlar, 133

74 Neal Robinson, Kur'an'ı Keşfetmek, çev. Süleyman Kalkan (İstanbul: Kuramer, 2018), 54.

75 Lokmân 31/2. 
414 | F. ARPAGUŞ / 'Lehve'1-Hadis'in Müziğe Tahsisinin Tefsir Açısından Değerlendirilmesi

âyetlerin bir rahmet ve yol gösterici olduğu ifade edilmektedir. ${ }^{76}$ Ardından, makalemizin de konusunu oluşturan lehve'l-hadis âyeti gelir ve bunu, bilgisizce Allah yolundan alıkoymak isteyen kimsenin niteliklerinin sayıldığı, Kur'ân âyetleri okunduğunda arkasını dönerek yüz çeviren kibirli kimsenin tasvir edildiği 7. âyet takip eder.

Sûrenin buraya kadarki kısmını, Kur'ân'ın ikili yapısı olduğunu belirten âyete ${ }^{77}$ istinaden değerlendirecek olursak, önce onun hikmetli âyetlerine kulak verip hidayete ve kurtuluşa eren iyilerden, sonra da kulaklarının üzerinde bir ağırlık varmış gibi onu dinlemeyip yüz çeviren inkârcı kimse(ler)den bahsedildiği ortadadır. Bu çiftli yapının, sûrenin kalan kısmıla alakası, şu şekilde kurulabilir:

Başta zikredilen ve iyiler için rahmet ve hidayet kaynağı olan hikmetli kitabın âyetleriyle, 12-19. âyetlerde iyi kullardan Lokmân'ın (a.s.) oğluna hikmetli sözlerle nasihatte bulunduğunu ifade eden âyetler birbiriyle irtibatlıdır. Sûrenin 6 ve 7. âyetlerinde tasvir edilen kimseyle de 6. âyette "bilgisizce" manasındaki aynı lafzı (بغير علم) içerisinde barındıran yirminci ve devamında, Allah hakkında bilgisizce mücadele eden, atalarının üzerinde bulunduğu yanlış yoldan vazgeçmeyen inkârcı kimselerin tasvir edildiği 21-30. âyetler irtibatlıdır. ${ }^{78} \mathrm{O}$ halde, lehve'lhadisten maksadın, Allah ve Rasûlünün dinlenmesini yasak ettiği ve Allah'ın yolundan alıkoyan bütün oyalayıcı sözler olduğunu söyleyen, bir sonraki âyetle de irtibatına değinerek lehve'l-hadisi umûm üzere alan, nüzûl ortamında âyetin hedef kitlesinin Müslümanlar değil inkârcılar olduğunu belirten Taberî'nin görüşü, kanaatimizce, en doğru hipotezi oluşturmaktadır. Lokmân sûresinin Mekkî olup ardından gelen 10 ylllık Medîne döneminde Hz. Peygamber'in (a.s.) lehve'l-hadisin müzik olduğuna dair herhangi bir açıklama yapmaması da manidardır.

\section{Sonuç}

Bu makalede, müziğin dinen yasaklandığına delil olduğu iddia edilen Lokmân sûresi 6. âyette yer alan lehve'l-hadis kavramının, klasik ve modern bazı kaynaklarda; fakat geneli de kapsayacak şekilde, ğinâ/müzik olarak tahsis edilmesi ele alınmıştır. Hadis ve tefsir

76 Lokmân 31/3-5.

77 ez-Zümer 39/23. Kur'ân'ın ikili yapısı hakkında ayrıntılı bilgi için bk. Abdulhamit Birışık, "es-Seb'u'l-Mesânî”, TDV İslâm Ansiklopedisi (İstanbul: TDV Yayınları, 2009), 36/261.

78 Bu konuda benzer bir değerlendirme için bk. İlyas Üzüm, "Lokman Sûresi”, Türkiye Diyanet Vakfı İslam Ansiklopedisi (İstanbul: TDV Yayınları, 2003), 27/210. 
kaynaklarında buna delil olduğu iddia edilen rivâyetlerin, fıkıh kitaplarında nasıl işlendiğine yer verilmiş ve kısaca mezheplerin görüşlerine değinilmiştir. Araştırma neticesinde, şu bulgulara ulaşılmıştır:

Çoğunluk lehve'l-hadisi ğinâ/müzik olarak tahsis etse de bu, üzerinde ittifak edilen bir tefsir/yorum şekli değildir. Âlimler içerisinde az da olsa lehve'l-hadisi şirk, eğlence gibi müzikten farklı değerlendirenler olmuştur. Mekkî sûrelerin muhtevalarında hak-batıl, iman-inkâr, dünya-ahiret, ceza ve mükâfat gibi ikili kavramlar, Kur'an'ın kendi tabi seyrinde yer alırken, mezkûr âyetin müziğin haramlığına delil olduğunu iddia etmek, daha sonrakilerin, nüzûlü tamam olmuş bir Kur'ân'dan geriye doğru bakarak meselenin fikhî hükmü için delil bulma gayretinde oldukları intibaını uyandırmaktadır. $\mathrm{Bu}$ yüzden, söz konusu meselede Taberî gibi, rivâyetleri, bağlamı ve lafzın umûmu üzere oluşunu dikkate alarak Allah yolundan alıkoyan her türlü sözün -ki müzik böyle bir amaca hizmet ediyorsa onun dalehve'l-hadis kapsamına girdiğini söyleyenler, bizce daha isabetlidir.

Bir diğer husus da senedinde ve sihhatinde problem olsa dahi, müfessir ve fukahâdan pek çok kimsenin, senet ve sıhhatindeki probleme rağmen bu rivâyetten müstağnî kalamaması düşündürücüdür. Ancak bu noktada asla bir kötü niyetten söz edilemez.

Bütün bunlardan sonra isyan, küfür, şirk, şehvet ve daha başka dinen hoş görülmeyen sözlerin ve bunlara eşlik eden müziğin dinen yasaklandığına delil bulunmak isteniyorsa, kitap ve sünnette, fuhşiyât ve münkerâtla alakalı pek çok nass vardır. Bu sebeple lehve'l-hadisi müziğe tahsis etmek, medeniyet iddiasındaki Müslümanların, insan fitratında var olan duyguların somut tezahürü olarak dışa vuran müzikle aralarına engel koymak anlamina gelir ki bizce bu, tercihe şâyân bir görüş değildir.

\section{Kaynakça}

Ahmed b. Hanbel, Ebû Abdillâh Ahmed b. Muhammed eş-Şeybânî. elMüsned. thk. Şuayb el-Arnaût vd.. 45 Cilt. Dımeşk: Müessesetü'rRisâle, 1421/2001.

Ahmed b. Hanbel, Ebû Abdullah Ahmed b. Muhammed. el-Müsned. thk. Ahmed Şakir vd.. 8 Cilt. Kahire: Dâru'l-Hadis, 1416/1995. 
416 | F. ARPAGUŞ / 'Lehve'1-Hadis'in Müziğe Tahsisinin Tefsir Açısından Değerlendirilmesi

Akdoğan, Bayram. "Bazı Âyet ve Hadisler Doğrultusunda, İslam Açısından Mûsikî Sanatının Değerlendirilmesi". Ankara Üniversitesi İlahiyat Fakültesi Dergisi 39/1 (Nisan 1999), 379-392.

Apaydın, Yunus. "Mûsikî". Türkiye Diyanet Vakfı İslam Ansiklopedisi. 31/261-263. İstanbul: TDV Yayınlar1, 2006.

Arpaguş, Safi. "Neyin Sırrı: Kemâle Yolculuk". Semazen. Erişim 25 Haziran 2020. https://semazen.net/neyin-sirri-kemale-yolculuksafi-arpagus/.

Ateş, Erdoğan. Türk Din Mûsikîsi. İstanbul: Rağbet Yayınları, 2. Basım, 2017.

Ayas, Mehmet. "Sema ve Devran Ritüellerinin Tasavvufi Eğitimdeki Yeri ve Mûsikî'nin Din Eğitiminde Değerlendirilmesi". Kilis 7 Aralı Üniversitesi Sosyal Bilimler Dergisi 8/15 (Haziran 2018), 1938.

Aynî, Ebû Muhammmed (Ebu's-Senâ) Bedrüddîn Mahmûd b. Ahmed. el-Binâye şerhu'l-Hidâye. 13 Cilt. Beyrut: Dâru'l-Kütübi'l-İlmiyye, $1420 / 2000$.

Bağdâdî, Ebû Muhammed el-Hâris b. Muhammed. Bugyetü'l-bâhis 'an zevâidi Müsnedi'l-Hâris. thk. Hüseyin Ahmed Sâlih el-Bâkirî. 2 Cilt. Medine: Merkezü Hidmeti's-Sünne ve's-Sîreti'n-Nebeviyye, 1413/1992.

Bağdâdî, Ebu'l-Hasen Ali b. Muhammed b. Muhammed b. Hubeyb. elHâvi'l-kebîr. thk. eş-Şeyh Ali Muhammed - eş-Şeyh Âdil Ahmed. 19 Cilt. Beyrut: Dâru'l-Kütübi'l-İlmiyye, 1419/1999.

Bezzâr, Ebûbekr Ahmed b. Amr Abdilhâlik. Müsnedü'l Bezzâr = elBahru'z-zehhâr. thk. Mahfûzu'r-Rahmân Zeynullâh. 18 Cilt. Medine: Mektebetü'l-Ulûm ve'l-Hikem, 1998.

Birışık, Abdülhamit. "es-Seb'u'l-Mesânî". Türkiye Diyanet Vakfı İslam Ansiklopedisi. 36/261-262. İstanbul: TDV Yayınları, 2009.

Buhârî, Ebû Abdillâh Muhammed b. İsmâîl. el-Edebü'l-müfred. thk. Semîr b. Emîr ez-Züheyrî. Riyad: Mektebetü Maârif, 3. Basım, 1409/1989.

Buhârî, Ebû Abdillâh Muhammed b. İsmâîl. Sahîhu'l-Buhârî. thk. Muhammed Züheyr b. Nâsır. 9 Cilt. b.y.: Dâru Tavki'n-Necât, 1422.

Buhârî, Ebu'l-Me'âlî Burhânüddîn Mahmûd b. Ahmed. el-Muhîtu'lburhânî fî finı'n-Nu'mânî. thk. Abdülkerîm Sâmî el-Cündî. 9 Cilt. Beyrut: Dâru'l-Kütübi'l-İlmiyye, 1424/2004. 
F. ARPAGUŞ / Evaluation of the Allocation of "Lahw al-hadith" to Music in Terms of Tafsir | 417

Can, Şefik. Konularına Göre Açıklamalı Mesnevî Tercümesi. 3 Cilt. İstanbul: Ötüken, 12. Basım, 2011.

Çağıl, Necdet. "Kutsal Metinler ve Müzik". Atatürk Üniversitesi İlahiyat Fakültesi Dergisi 39 (2013) 1-46.

Demirci, Muhsin. Kur'ân Tefsirinde Farklı Yorumlar. 3 Cilt. İstanbul: İ́av Yayınları, 2017.

Düzenli, Pehlül. "Klasik İslâm Kaynaklarında Müzik Tartışmaları". Marife 1/2 (Aralık 2001), 27-58.

Erdoğan, Mehmet. Fıkıh ve Hukuk Terimleri Sözlüğ̈̈. İstanbul: Ensar Yayınları, 3. Basım, 2010.

Ezdî, Ebu'l-Hasen Mukâtil b. Süleymân. Tefsîru Mukâtil b. Süleymân. thk. Abdullâh Mahmût Şehhâte. 5 Cilt. Beyrut: Dâru İhyâi't-Türâs, 1423.

Fâkihî, Ebû Abdillâh Muhammed b. İshâk b. Abbâs. Ahbâru Mekke. thk. Abdülmelik Abdullâh Düheyş. 6 Cilt. Beyrut: Dâru Hıdr, 2. Basım, 1414.

Kur'an-ı Kerim ve İzahlı Meali (Türkçe Anlamı). çev. Muhammed Hamdi Yazır. İstanbul: Nizam yayınları, 1998.

Kur'an-ı Kerim ve İzahlı Meali (Türkçe Anlamı). çev. Sadreddin Gümüş vd.. İstanbul: İpek Yayınları, 1997.

Güvendi, Sümeyra. Fıkıhda Lehv (Oyun ve Eğlence). Konya: Selçuk Üniversitesi, Sosyal Bilimler Enstitüsü, Yüksek Lisans Tezi, 2008.

Hamidullah, Muhammed. İslâm Peygamberi. çev. Salih Tuğ. 2 Cilt. İstanbul: İrfan Yayımcilık ve Ticaret, 1993.

Hanefî, İbn Âbidîn Muhammed Emîn b. Ömer b. Abdülazîz. Reddü'lmuhtâr. 6 Cilt. Beyrut: Daru'l-Fikr, 1412/1992.

İbn Ebî Şeybe, Ebû Bekr Abdullāh b. Muhammed el-Absî el-Kûfî. elMusannef. thk. Kemal Yusuf el-Hût. 7 Cilt. Riyad: Mektebetü Rüşd, 1409.

İbn Kesîr, Ebü'l-Fidâ' İmâdüddîn İsmâîl b. Şihâbiddîn Ömer b. Kesîr b. Dav' b. Kesîr el-Kaysî el-Kureşî. Tefsîru'l-Kur'âni'l-'azîm. thk. Sâmî b. Muhammed Sellâme. 8 Cilt. b.y.: Dâru Tayyibe li'n-Neşr, 1420/1999.

İbn Manzûr, Muhammed b. Mükerrem. Lisânü'l-'Arab. 15 Cilt. Beyrut: Dâru Sâdır, 3. Basım, 1414.

İnanır, Ahmet. "XVI. Yüzyıl Osmanlı Fakih ve Sûfîlerinin Semâ, Raks ve Devrân Tartışmalarında Lehte ve Aleyhte Kullandıkları Hukûki 
Deliller ve Değerlendirilmesi”. Cumhuriyet Üniversitesi İlahiyat Fakültesi Dergisi. 17/2 (Aralık 2013), 237-269.

İsfahânî, Ebü'l-Kâsım Hüseyin b. Muhammed b. Mufaddal er-Râgıb. elMüfredât fì ğarîbi'l-Kur'ân. thk. Safvân Adnân. Beyrut: Dâru'lKalem, 1412.

Karaman, Hayrettin. Günlük Hayatımızda Helaller ve Haramlar. İstanbul: İz Yayıncılık, 2008.

Kâtib Çelebi, Hacı Halîfe. Keşfü'z-zunûn 'an esâmi'l-kütübi ve'l-fünûn. 2 Cilt. Lübnan: Dâru'l-Kütübi'l-İlmiyye, 1941.

Kattân, Mennâ' b. Halîl. Mebâhis fi ulûmi'l-Kur'ân. Riyad: Mektebetü'lMaarif, 3. Basım, 1421/2000.

Kaya, Şinasi. Ne Ifrat Ne Tefrit Musıkî Hakkında Tam Tespit. Samsun: y.y., 1993.

Kayrevânî, Yahyâ b. Sellâm b. Ebî Sa'lebe et-Teymî. Tefsîru Yahyâ b. Sellâm. thk. Hind b. Şelebî. 2 Cilt. Beyrut: Dâru'l-Kütübi'l-İlmiyye, $1425 / 2004$.

Kettânî, Muhammed Abdülhayy b. Abdilkebîr b. Muhammed el-Hasenî el-İdrîsî. et-Terâtibü'l-idâriyye. thk. Abdullah el-Hâlidî. 2 Cilt. Beyrut: Şeriketü Dâri'l-Erkâm, 2008.

Koca, Ferhat. İslâm Hukuk Metodolojisinde Tahsis (Daraltıcı Yorum). İstanbul: İSAM Yayınları, 2010.

Kur'ân-ı Kerîm ve İzahlı Meâli (Türkçe Anlamı). çev. Muhammed Hamdi Yazır. haz. Dücane Cündioğlu. İstanbul: Nizam Yayınları, 1998.

Kurban, Yasin. "İnsan Tabiatı ve İslam Açısından Müzik (Müzik-Fıtrat İlişkisi)." Atatürk Üniversitesi Sosyal Bilimler Dergisi 23/1 (Mart 2019), 21-36.

Kurtubî, Ebu'l-Velîd Muhammed b. Ahmed b. Rüşd. el-Beyân ve't-tahsîl. thk. Muhammed Hâcî vd.. 20 Cilt. Beyrut: Dâru'l-Garbi'l-İslâmî, 3. Basım, 1408/1988.

Mahzûmî, Ebu'l-Haccâc Mücâhid b. Cebr et-Tâbi'î el-Mekkî. Tefsîru Mücâhid. thk. Muhammed Abdüsselâm Ebu'n-Nîl. Misır: Dâru'lFikri'l-İslâmî, 1410/1980.

Misrî, Ebû Muhammed Abdullâh b. Vehb b. Müslim. Tefsîru'l-Kur'ân. thk. Miklos Morânî. b.y.: Dâru'l-Garbi'l-İslâmî, 2003.

Râzî, Zeynüddîn Ebû Abdillâh Muhammed b. Ebîbekr b. Abdilkâdir. Muhtâru's-sihâh. thk. Yûsuf eş-Şeyh Muhammed. Beyrut: elMektebetü'1-Asriyye, 5. Basım, 1420/1999. 
Robinson, Neal. Kur'an'ı Keşfetmek. çev. Süleyman Kalkan. İstanbul: Kuramer, 2018.

Sevrî, Ebû Abdillâh Süfyân b. Saîd b. Mesrûk. Tefsîru's-Sevrî. Beyrut: Dâru'l-Kütübi'l-İlmiyye, 1403/1983.

Şâfiî, Ebû Abdillâh Muhammed b. İdrîs b. Abbâs. el-Ümm. 8 Cilt. Beyrut: Dâru'l-Marife, 1410/1990.

Şeybânî, Ebû Abdillâh Muhammed b. el-Hasen b. Ferkad. el-Asl. thk. Muhammed Boynukalın. 12 Cilt. Beyrut: Dâru İbn Hazm, $1433 / 2012$.

Taberânî, Ebu'l-Kâsım Müsnidü'd-dünya Süleymân b. Ahmed. elMu'cemü'l-kebîr. thk. Hamdî b. Abdülmecîd es-Selefî. 25 Cilt. Kahire: Mektebetü İbn Teymiye, 2. Basım, 1415/1995.

Taberî, Ebû Ca'fer Muhammed b. Cerîr b. Yezîd el-Âmülî. Câmi'u'l-beyân fî te'vîli'l-Kur'ân. thk. Ahmed Muhammed Şâkir. 24 Cilt. b.y.: Müessesetü'r-Risâle, 1420/2000.

Tıraşc1, Mehmet. "İslam'da Mûsikî”. Türk Din Mûsikîsi El Kitabı. ed. Ahmet Hakkı Turabi. 14-23. Ankara: Grafiker, 2017.

Tirmizî, Ebû Îsâ Muhammed b. Îsâ b. Sevre. el-Câmi'u'l-kebîr = Sünen. thk. Beşşâr Avvâd Marûf. 6 Cilt. Beyrut: Dâru'l-Garbi'l-İslâmî, 1998.

Turabi, Ahmet Hakkı. "Mûsikî". Türk Din Mûsikîsi El Kitabı. ed. Ahmet Hakkı Turabi. 11-14. Ankara: Grafiker, 2017.

Tûfî, Süleymân b. Abdülkavî b. Abdülkerîm Necmüddîn. el-İşârâtü'lilâhiyye ile'l-mebâhisi'l-usûliyye. thk. Ebû Âsım Hasan b. Abbâs b. Kutb. 3 Cilt. Kahire: el-Fârûku'l-Hadisiyye, 1423/2002.

Üzüm, İlyas. "Lokmân Sûresi”. Türkiye Diyanet Vakfi İslam Ansiklopedisi. 27/209-210. İstanbul: TDV Yainları, 2003.

Yüksel, Mukadder Arif. “Kur'ân'da Hadis Kelimesinin Semantik Anlamı". Bozok Üniversitesi İlahiyat Fakültesi Dergisi 6/2 (2017), 135-155. 